\title{
PENDAMPINGAN PENINGKATAN KEMAMPUAN MEMBACA AL-QUR'AN BAGI KADER AISYIYAH RANTING NGADIREJO PADA MASA PANDEMI COVID-19
}

\author{
Main Sufanti ${ }^{1}$, Beti Kurniawati ${ }^{1}$, Maryam Sri Muhaimini ${ }^{1)}$, Jeni Nur Cahyati ${ }^{1)}$ \\ 1)Pendidikan Bahasa dan Sastra Indonesa, FKIP,Universitas Muhammadiyah Surakarta, Jawa Tengah, Indonesia \\ Corresponding author : Main Sufanti \\ E-mail : ms258@ums.ac.id
}

Diterima 11 November 2021, Disetujui 18 November 2021

\begin{abstract}
ABSTRAK
Ranting Aisyiyah Ngadirejo Kartasura telah menyelenggarakan pembelajaran membaca Al-Qur'an bagi ibu-ibu jamaah pengajian. Sebelum pandemi ada 4 kelompok belajar yaitu kelompok Al-Hidayah, AlHidayah Klinggen, Al-Fadhilah, dan Pucangan. Namun, saat pandemi Covid-19 kelompok belajar ini berhenti. Survei terhadap peserta menunjukkan adanya ibu-ibu yang belum mahir membaca Al-Qur'an, maka pembelajaran perlu dilanjutkan. Kegiatan pengabdian masyarakat ini bertujuan untuk (1) meningkatkan partisipasi ibu-ibu anggota Aisyiyah Ngadirejo Kartasura dalam penyelengaraan kelompok belajar Al-Qur'an di masa pandemi dan (2) meningkatkan kemampuan membaca Al-Qur'an dengan benar dan lancar bagi ibu-ibu Aisyiyah Ngadirejo Kartasura. Solusi yang ditawarkan adalah pendampingan belajar membaca Al-Qur'an dalam kelompok-kelompok kecil dengan metode iqra. Kegiatan ini dilaksanakan melalui 8 tahap, yaitu eksplorasi, analisis kebutuhan, penyusunan program, sosialisasi pendataan peserta, pembentukan kelompok belajar, pendampingan belajar, dan evaluasi. Kegiatan dilaksanakan selama 8 bulan sejak September 2020-April 2021. Hasil pengabdian ini adalah (1) Ditinjau dari kerjasama, program ini dapat mempererat kerjasama antara Universitas Muhamamdiyah Surakarta, PRA Ngadirejo, dan TPA Al-Hidayah. (2) Ditinjau dari proses penyelenggaraan kegiatan belajar Al-Qur'an ini telah berhasil menyelenggarakan 2 kelompok belajar yaitu Al-Fadhilah dan Al-Hidayah dengan protokol kesehatan. (3) Ditinjau dari peningkatan kemampuan peserta, program ini dapat meningkatkan kemampuan peserta dalam membaca Al-Qur'an, yakni meningkatnya jilid iqra dan surat Al-Qur'an yang dipelajari.
\end{abstract}

Kata Kunci: kelompok belajar Al-Qur'an; anggota Aisyiyah; metode iqra; pandemi covid-19

\begin{abstract}
Ranting Aisyiyah Ngadirejo Kartasura has organized learning to read the Qur'an for mothers of recitation congregations. Before the pandemic there were 4 study groups, namely the Al-Hidayah, Al-Hidayah Klinggen, Al-Fadhilah, and Pucangan groups. However, during the Covid-19 pandemic this study group stopped. The survey of participants showed that there were mothers who were not proficient at reading the Qur'an, so learning needed to be continued. This community service activity aims to (1) increase the participation of women members of Aisyiyah Ngadirejo Kartasura in organizing Al-Qur'an study groups during the pandemic and (2) improve the ability to read the Koran correctly and fluently for mothers. Aisyiyah Ngadirejo Kartasura. The solution offered is mentoring in learning to read the Qur'an in small groups using the iqra method. This activity was carried out through 8 stages, namely exploration, needs analysis, program preparation, socialization of participant data collection, formation of study groups, study assistance, and evaluation. The activity was carried out for 8 months from September 2020-April 2021. The results of this service were (1) In terms of collaboration, this program could strengthen cooperation between the Muhammadiyah University of Surakarta, PRA Ngadirejo, and TPA Al-Hidayah. (2) Judging from the process of organizing this Al-Qur'an learning activity, it has succeeded in organizing 2 study groups, namely Al-Fadhilah and Al-Hidayah with health protocols. (3) In terms of increasing the ability of participants, this program can improve the ability of participants in reading the Qur'an, namely increasing the volume of iqra and the letters of the Qur'an that are studied.
\end{abstract}

Keywords: Al-Qur'an study group; Aisyiyah members; iqra method; Covid-19 pandemic

\section{PENDAHULUAN}

Ngadirejo adalah salah satu kelurahan di Kecamatan Kartasura, Sukoharjo, Jawa Tengah. Kelurahan Ngadirejo berada di Jl.
Keden No. 30 Kartasura, Kode Pos 57163. Blog Kelurahan Ngadirejo (202017a) menyebutkan kelurahan ini memiliki 9 Rukun Warga $(\mathrm{Rw})$ dan 32 Rukun Tetangga (Rt). Berdasarkan data 
pada blog ini jumlah penduduk di Ngadirejo yang beragama Islam mencapai $85 \%$. Umat muslim di kelurahan ini mempunyai 10 musala dan 12 masjid yang berpotensi menggairahkan kegiatan bagi umat Islam.

Berbagai organisasi dan kelompok pengajian turut mewarnai semangat keislaman kelurahan ini. Kondisi ini memberikan dampak positif dan negatif masyarakat dalam berislam. Dampak positifnya ialah terjalinnya muamalah yang baik ketika sering diadakan syiar Islam. Adapun dampak negatifnya apabila ada pandangan Islam yang berbeda sehingga menimbulkan sekat antarumat Islam. Munculnya tingkat dan sekat menyebabkan sulitnya dakwah Muhammadiyah di Desa Ngadirejo (Suryanto, 2016: 11). Keberagaman organisasi keagamaan merupakan salah satu kesulitan Muhammadiyah dalam berdakwah.

Hasil survei memperlihatkan pengajian yang diselenggarakan selalu didominasi oleh kaum ibu-ibu, bahkan ada kelompok yang menyelenggarakan pengajian khusus ibu-ibu. Misalnya, pengajian umum yang diadakan Kelurahan Ngadirejo setiap ahad pagi. Berdasarkan hasil observasi, dari sekitar 180 jamaah sekitar $70 \%$ didominasi oleh ibu-ibu. Di samping itu, juga banyak pengajian yang khusus ibu-ibu, antara lain: pengajian rutin 'Aisyiyah, pengajian PKK setiap RT, dan Pengajian PKK setiap RW. Banyaknya ibu-ibu yang menghadiri berbagai kegiatan pengajian menunjukkan adanya rasa semangat dalam mencari ilmu.

Kegairahan mencari ilmu ini berhenti total ketika pandemi Covid-19 melanda masyarakat. Namun, setelah pada September 2020 dan selanjutnya dimulai adaptasi baru. Kondisi ini memberi peluang untuk diselenggarakannya pembelajaran Al-Qur'an supaya ingatan membaca tidak tergerus waktu. Kegiatan belajar harus dilakukan secara kontinu supaya melahirkan daya serap yang baik terhadap materi yang dipelajari (Ahmad, Bonso, \& Samsiah, 2021). Kegiatan belajar ini tentu selalu dilaksanakan dengan menerapkan protokol kesehatan yang ketat.

Analisis situasi menemukan masalah yang mendesak untuk segera dilaksanakan kegiatan supaya ibu-ibu yang belum mahir membaca Al-Qur'an bisa mahir dan yang belum bisa supaya bisa. Masih ada jamaah Aisyiyah yang belum mahir membaca, bahkan ada juga yang belum bisa membaca sama sekali. Penyelenggaraan kelompok belajar Al-Qur'an sebelum pandemi belum mampu menuntaskan ibu-ibu dalam membaca Al-Qur'an. Berdasarkan survei yang telah dilakukan, kemampuan ibu-ibu ini beragam. Ada yang mengaku sama sekali belum bisa membaca, karena kurangya fasilitas belajar ketika kecil. Ada yang sudah bisa tetapi lupa karena kurang dibiasakan membaca Al-Qur'an. Selain itu, ada pula yang membacanya masih mengeja sehingga perlu dibimbing untuk mencapai kelancaran dalam membaca.

Menurut data 2013, Aisyiyah Ranting Ngadirejo beranggota 68 ibu-ibu (Fatimah dan Sufanti, 2013b). Sejumlah 38 orang (56\%) menyatakan mahir membaca Al-Qur'an, 17 orang $(25 \%)$ belum bisa membaca Al-Qur'an, dan 13 orang $(19 \%)$ memerlukan bimbingan dalam belajar Al-Qur'an. Dari analisis data ini, terdapat 30 orang $(44 \%)$ anggota Aisyiyah Ngadirejo masih memerlukan pendampingan belajar membaca Al-Qur'an. Pada saat itu, pendampingan sangat diperlukan dan dikhususkan bagi ibu-ibu yang menyatakan belum bisa membaca Al-Qur'an yakni sejumlah 17 orang $(25 \%)$. Kondisi ini memperlihatkan bahwa perlu diadakan kelompok-kelompok belajar Al-Qur'an untuk memberantas buta huruf Al-Quran.

Buta aksara Al-Qur'an merupakan kondisi dimana seseorang tidak mampu membaca atau belum mengenal dan menulis aksara yang membentuk kalimat dalam ayat suci Al-Qur'an, sehingga ditakutkan tidak memiliki pemahaman makna yang termuat dalam setiap ayat sebagai pedoman hidup umat muslim (Yasin; Muklisin, 2019: 48). Kemampuan membaca Al-Qur'an dapat meningkat melalui pembelajaran dini atau ketika fase anak-anak (Sadiah, Maya, \& Wahidin, 2018). Pada fase belajar, anak-anak didik untuk mengingat huruf hijaiyah, membaca, dan memahami makna yang terkandung dalam ayat Al-Qur'an. Dengan bimbingan yang konsisten dan terus-menerus, seseorang akan lancar membaca Al-Qur'an. Belajar Al-Qur'an itu seperti belajar bahasa Inggris, ditekan pada praktiksi dan dilakukan secara kontinu, supaya ilmu yang diserap tidak mudah hilang.

Belajar Al-Qur'an dimudahkan dengan adanya transkrip yang menuntun untuk belajar membaca dengan pelafalan bunyi. Ada pun makna dan arti diberikan melalui terjemahan ayat suci Al-Qur'an. Kemampuan memahami transkrip dan terjemahan Al-Qur'an dianjurkan untuk dikuasai oleh setiap umat Islam. Menurut Tarigan, Ngalim Purwanto, dan Djeniah Alim (dalam Rahman, 2019, 282) keterampilan membaca itu dibedakan menjadi dua, yakni (1) membaca permulaan, di antaranya keterampilan melafalkan aksara-aksara hijaiyah, seperti alif, ba', ta', dan seterusnya dalam bentuk kata, frasa, maupun klausa serta kalimat dengan benar; (2) membaca lanjut, yakni keterampilan pemahaman terhadap makna dan arti dari bacaan ayat suci Al-Qur'an. 
Kegiatan pembelajaran Al-Qur'an perlu diadakan untuk menfasilitasi ibu-ibu yang belum mendapatkan pelajaran membaca AlQur'an di waktu kecil. Ibu-ibu anggota Aisyiyah Ngadirejo ini sangat bersemangat dalam menuntut ilmu yang dbuktikan dengan keaktifannya menghadri acara pengajian. Dalam acara pengajian, penceramah tentu menyisipkan ayat suci Al-Qur'an sebagai landasan ceramahnya. Pemahaman terhadap isi ceramah ini akan dimaknai seiring dengan pemahaman setiap ayat Al-Qur'an. Sebagaimana firman Allah Swt. dalam Q.S. AlBaqarah(2):185) yang artinya,"Bulan Ramadan, bulan diturunkan Al-Qur'an sebagai pedoman dan petunjuk bagi manusia yang disertai penjelasan dari setiap petunjuk itu dan pembeda antara yang hak dan batil..."

Sebelum pandemi, di Aisyiyah ranting Ngadieejo telah terbentuk 4 kelompok belajar Al-Qur'an bagi ibu-ibu. Namun, begitu datang masa pandemi, kegiatan di semua kelompok ini berhenti. Berdasarkan survei, belum semua ibu-ibu peserta kelompok bisa membaca AlQur'an dengan lancar. Oleh karena itu, perlu dicari solusi penyelenggaraan kelompok belajar dalam masa pandemi..

Pengabdian masyarakat ini bertujuan untuk: (1) meningkatkan partisipasi ibu-ibu anggota ranting Aisyiyah Ngadirejo Kartasura dalam penyelenggaraan kelompok belajar AlQur'an di masa pandemi Covid-19 dan (2) meningkatkan kemampuan membaca AlQur'an dengan benar dan lancar bagi ibu-ibu ranting Aisyiyah Ngadirejo Kartasura dalam kegiatan kelompok belajar Al-Qur'an di masa pendemi Covid-19.

\section{METODE}

Kegiatan pengabdian masyarakat ini dilaksanakan di Kelurahan Ngadirejo, Kartasura, Sukoharjo, Jawa Tengah pada September 2020 sampai April 2021. Kegiatan ini dilakukan dalam kelompok-kelompok belajar berdekatan dengan tempat tinggal ibu-ibu, dibimbing oleh tutor, dengan metode iqra, dan menerapkan protokol kesehatan yang ketat.

Kegiatan ini dilaksanakan bersamasama antara tim pengabdian masyarakat dari Universitas Muhammadiyah Surakarta, Pimpinan Ranting Aisyiyah (PRA) Ngadirejo, dan Taman Pendidikan Al-Qur'an (TPA) AlHidayah Karang Tengah. Tim pengabdian masyarakat dari UMS terdiri 2 dosen dan 2 mahasiswa bertugas merancang program, melakukan koordinasi pelaksanaan program, dan mengadakan evaluasi. PRA Ngadirejo bertugas memotivasi dan mendata ibu-ibu peserta dan menyediakan tempat pelaksanaan pembelajaran. Adapun TPA Al-Hidayah bertugas menyediakan tutor sesuai jadwal yang disepakati.

Pelaksanaan pengabdian masyarakat ini meliputi prosedur yaitu: eksplorasi, analisis kebutuhan, penyusunan program, sosialisasi kegiatan, pendataan peserta, pembentukan kelompok belajar, pendampingan belajar, dan evaluasi.

\section{HASIL DAN PEMBAHASAN \\ Pelaksanaan Program}

Pelaksanaan kegiatan ini sesuai dengan prosedur yang meliputi 8 tahap sebagai berikut

\section{Tahap Eksplorasi}

Tim pengabdian masyarakat dari UMS melakukan eksplorasi pada September 2020. PRA Ngadirejo, Kartasura memberikan izin dalam pelaksanaan kegiataan pengabdian ini dan pimpinan PRA menyatakan siap bekerja sama, serta mendukung penyelenggaraan kegiatan kelompok belajar Al-Qur'an.

Tujuan dari tahap eksplorasi ini adalah untuk memperoleh data mengenai kemampuan ibu-ibu RA Ngadirejo secara umum dan kemampuan anggota muslimat dalam membaca Al-Qur'an. Survei dilakukan oleh tim pengabdian masyarakat secara online kepada kelompok belajar yang telah ada sebelum masa pandemi.

Survei dilakukan di beberapa kelompok belajar. Sebelum pandemi ada 4 kelompok belajar yaitu kelompok Al-Hidayah Karang Tengah, kelompok Klinggen, kelompok AlFadhilah Karang Tengah, dan kelompok Pucangan. Namun, pada saat pandemi semua kelompok kegiatannya terhenti. Tim pengabdian masyarakat bekerja sama dengan PRA Ngadirejo memotivasi dan mendata ibuibu yang sebelum pandemi telah belajar membaca Al-Qur'an. Hasilnya, hanya 2 kelompok yang bisa diselenggarakan yaitu kelompok Al-Fadhilah Karang Tengah dan kelompok Klinggen. Kelompok yang lain tidak bersedia dengan alasan suasana pandemi yang masih mengkhawatirkan.

Hasil survei terhadap 2 kelompok ini memperlihatkan kemampuan ibu-ibu anggota Aisyiyah ranting Ngadirejo dalam membaca AlQur'an bervariasi, yakni: ada yang mahir, lancar, kurang lancar, dan belum bisa. Di kedua kelompok belajar ini terdapat ibu-ibu yang kurang lancar dan belum bisa membaca AlQur'an.

Hasil survei menunjukkan adanya ibu-ibu yang belum mahir membaca Al-Qur'an diperkuat oleh hasil analisis dokumen. Berdasarkan pendataan tahun 2017, masih diperlukan pendampingan bagi anggota Aisyiyah ranting Ngadirejo yang perlu belajar 
Al-Qur'an (Sufanti, Ihsanusin, dan Hidayah, 2017). Pendampingan ini berjumlah 20 orang dengan rincian pendampingan khusus terhadap ibu-ibu yang belum mahir membaca Al-Qur'an sejumlah 17 orang dan 3 orang yang belum bisa membaca Al-Qur'an. Setelah dilakukan pendampingan belajar, 12 orang sudah bisa membaca Al-Qur'an, 2 orang Juz Amma, dan 6 orang masih dalam tahap iqra antara jilid 2 sampai 6. Data ini menunjukkan adanya pengurangan kasus buta huruf Al-Qur'an yang pernah dilakukan oleh tim pengabdian masyarakat sebelumnya.

\subsection{Tahap Analisis Kebutuhan}

Pada tahap eksplorasi ditemukan dua kelompok belajar ibu-ibu belum mahir dan belum bisa membaca Al-Qur'an. Sebelum pandemi mereka telah belajar, tetapi belum lulus atau belum bisa membaca Al-Qur'an dengan lancar. Kondisi ini memperlihatkan adanya kebutuhan pendampingan lanjutan untuk belajar membaca Al-Qur'an agar mereka bisa tuntas (lancar atau mahir) membaca AlQur'an. Diperlukan fasilitas untuk mendukung semangat ibu-ibu yang rajin ikut pengajian, namun belum lancar membaca Al-Qur'an agar mereka mampu belajar dengan mudah dan murah

\subsection{Penyusunan Program}

Program pengabdian masyarakat ini dilaksanakan selama 8 bulan sejak September 2020 - April 2021. Tim pengabdian masyarakat merencanakan program ini dan menawarkannya kepada mitra kerja, yakni kelompok Al-Fadhilah Karang Tengah dan kelompok Klinggen. Adapun program yang disepakati sebagai berikut.

a. Pendataan ibu-ibu yang belum mahir dan belum bisa membaca Al-Qur'an dilakukan dengan segera dan melakukan konfirmasi kesediaan mengikuti pembelajaran. Kegiatan ini dibantu oleh PRA Ngadirejo.

b. Pembentukan kelompok belajar sesuai tingkata iqra dan tempat tinggal dilaksanakan dengan segera.

c. Metode iqra merupakan metode yang digunakan dalam pembelajaran Al-Qu'ran ini. Perlu segera disediakan buku iqra, Cara Cepat Belajar Membaca Al-Qur'an (jilid 1-6).

d. Pelaksanaan kelompok belajar harus memperhatikan protokol kesehatan secara ketat, sehingga tim harus menyediakan masker, hand sanitizer, dan sabun cuci tangan.

e. Tim pengabdian masyarakat sebagai koordinator seluruh kegiatan, PRA Ngadirejo sebagai motivator dan penyedia tempat kegiatan, sedangkan TPA AlHidayah sebagai penyedia tutor.

Metode iqra dipilih dalam kegiatan ini karena metode ini juga yang diterapkan dalam pelaksanaan kegiatan sebelum masa pandemi, sehingga bersifat melanjutkan. Di samping itu, metode iqra memiliki keunggulan sebagai cara cepat dalam membaca Al-Qur'an yaitu menekankan langsung pada latihan membaca yang terdiri dari 6 jilid pada buku panduan Iqro' (Zulfitria \& Arif, 2019). Di setiap jilidnya dilengkapi petunjuk belajar yang memudahkan peserta didik (ibu-ibu) dalam belajar membaca Al-Qur'an.

\subsection{Sosialisasi Kegiatan}

Sosialisai kegiatan dilaksanakan secara daring melalui group WhatsApp PRA Ngadirejo. Kegiatan ini berupa menginformasikan program belajar Al-Qur'an yang akan segera dilaksanakan. Oleh karena itu, ibu-ibu yang belum lancar membaca atau belum bisa membaca dimotivasi untuk segera mendaftarkan diri. Selain menginformasikan program ini, tim juga memotivasi kepada ibu-ibu agar mereka aktif dan kompak dalam belajar AlQur'an karena manfaat membaca Al-Qur'an sangat banyak.

Membaca Al-Qur'an memang penting dan bermanfaat. Membaca Al-Qur'an akan berpengaruh terhadap jiwa seseorang yang bersih dan suci sehingga memiliki pendirian yang kuat, tidak mudah terpengaruh dengan hal negatif (Subir, 2019). Membaca Al-Qur'an beserta maknanya sangat bermanfaat pada aspek psikologis yaitu dapat mengurangi tingkat depresi dan mereduksi ketegangan syaraf sehingga membuat seseorang menjadi rileks (Jariah, 2019). Hal ini membuktikan bahwa Al-Qur'an dapat menjadi penawar dan rahmat dari Allah Swt. kepada hamba-Nya yang beriman.

\subsection{Pendataan Peserta}

Dengan dibantu PRA Ngadirejo, pendataan peserta dilakukan. Pendataan dilakukan dengan meminta kepada ibu-ibu peserta untuk mengisi formulir pendaftaran. Pendataan ini menghasilkan data ibu-ibu yang beralamatkan di Kelurahan Ngadirejo sebanyak 20 orang bersedia belajar Al-Qur'an dan menyatakan belum bisa atau belum lancar membaca Al-Qur'an.

\subsection{Pembentukan Kelompok}

Tim pengabdian masyarakat membentuk kelompok belajar berdasarkan tempat dan tingkatan iqra. Hal ini dilakukan untuk memudahkan dalam penyelenggaraan pembelajaran, terutama dekat dengan rumah 
para ibu-ibu yang belajar. Berdasarkan data yang ada, maka dibentuklah 2 kelompok berdasarkan tempat tinggal seperti yang ditunjukkan pada Tabel 1.

Tabel 1. Kelompok Belajar Al-Qur'an

\begin{tabular}{cll}
\hline NNo. & $\begin{array}{c}\text { Tempat Kelompok } \\
\text { Belajar }\end{array}$ & $\begin{array}{c}\text { Jumlah } \\
\text { Peserta }\end{array}$ \\
\hline 1. & $\begin{array}{l}\text { TPA Al-Fadhilah, } \\
\text { Karang Tengah }\end{array}$ & 11 orang \\
\hline 2. & TPA Klinggen & 9 orang \\
\hline
\end{tabular}

\subsection{Pendampingan Belajar}

Pendampingan belajar ibu-ibu Aisyiyah dilakukan oleh tim pengabdian masyarakat PRA Ngadirejo dan TPA Al-Hidayah sesuai jadwal yang telah disepakati. Kelompok Klinggen diselenggarakan setiap Sabtu, pukul 15.30-17.00 WIB di Masjid Jami' Aisyiyah Klinggen. Adapun kelompok Al-Fadhilah diselenggarakan setiap Senin, Rabu, dan Kamis pada pukul 15.30-17.00 WIB di masjid Al-Fadhilah Karang Tengah.

Metode iqra menjadi metode pembelajaran yang dipilih untuk belajar AlQur'an. Oleh karena itu, sarana yang disediakan adalah buku iqra jilid 1 sampai 6 dan kartu prestasi. Dalam pembelajaran Al-Qur'an, tim pengabdi menerapkan metode iqra yang ditekankan pada pendekatan individual. Metode iqra memiliki 5 prinsip utama, yaitu: (1) membaca langsung (tanpa dieja atau diurai), (2) tatap muka langsung (musyahadah), (3) berdasarkan prinsip BSA atau bahasa sasaran, (4) dapat melalui sistensi, dan (5) menggunakan metode modul (Yahya et al., 2019). Metode iqra yang digunakan oleh tim pengabdi ialah secara tatap muka langsung dengan menggunakan modul buku iqra. Bersama tutor atau tim pengabdi, ibu-ibu diminta membaca iqra sesuai tingkatannya. Belajar dengan pendampingan teman sebaya akan menciptakan suasana belajar yang nyaman (Permana \& Rizqi, 2021)(Permana and Rizqi 2021)(Permana and Rizqi 2021)(Permana and Rizqi 2021)(Permana and Rizqi 2021)(Permana and Rizqi 2021)(Permana and Rizqi 2021)(Permana \& Rizqi, 2021). Apabila terjadi kesalahan dalam membaca, tim tutor langsung membenarkan hingga ibu-ibu mampu membaca dengan lancar dan benar.

Setiap kelompok belajar didampingi oleh 3-5 tutor yang disediakan oleh TPA Al-Hidayah Karang Tengah. Pada setiap kegiatan, setiap peserta secara individual praktik membaca huruf Arab di dalam buku iqra pada jilid dan halaman tertentu di hadapan seorang tutor. Jika pada halaman ini sudah lancar, maka dilanjutkan pada halaman berikutnya. Oleh karena itu, pencapaian masing-masing peserta berbeda-beda.

Pendampingan belajar ini direncanakan selama 8 bulan sejak September 2020-April 2021. Kegiatan pendampingan dilaksanakan secara luring sehingga sangat dipengaruhi oleh suasana pandemi. Kegiatan sering tidak dapat dilaksanakan karena adanya PPKM (Pemberlakuan Pembatasan Kegiatan Masyarakat). Pada September-Desember 2020, kegiatan lancar, hanya beberapa kali berhenti. Namun, pada Januari-April 2021 kegiatan sama sekali tidak bisa dilaksanakan. Tim pengabdian menawarkan kepada peserta untuk kegiatan daring, tetapi banyak kendala yang belum bisa diatasi, terutama peserta belum bisa menguasai teknologi daring.

Pada masa pandemi aktivitas pembelajaran tidak bisa dilaksanakan dengan luring. Namun, ibu-ibu belum bersedia belajar Al-Qur'an secara jarak jauh (daring) karena berbagai sebab, antara lain: kurang menguasai teknologi, kurang fasilitas teknologi, kesibukan mengurus anak yang juga belajar jarak jauh, dan sebagainya. Kendala-kendala ini secara umum dialami oleh guru pembelajaran jarak jauh. Hasil penelitian Fikri, et al. (2021) menemukan kendala pembelajaran jarak jauh yang dialami oleh pengajar dan peserta didik ialah kurangnya pemahaman penggunaan aplikasi pembelajaran dan kendala jaringan internet. Selain itu, banyak guru dan peserta didik yang belum menguasai learning management system (LMS) berupa software atau aplikasi yang melibatkan jaringan internet dalam pelaksanaannya (Nafiah, Ghufron, \& Hartatik, 2021). Hal ini menjadi kendala umum yang dialami guru dan peserta didik dalam melaksanakan pembelajaran jarak jauh.

\subsection{Evaluasi Program}

Evaluasi yang dilakukan oleh tim pengabdian masyarakat bertujuan untuk mengetahui perkembangan proses pembelajaran dan hasil yang berupa kemampuan ibu-ibu Aisyiyah dalam membaca Al-Qur'an. Prosedur evaluasi yang diharapkan sesuai dengan tujuan pengabdian masyarakat yang meliputi ruang lingkup pengetahuan, sikap, dan perilaku, serta keterampilan. Menurut (Sauri, Amri, Jumadi, Najwa, \& Hapsah, 2021) proses evaluasi dalam pembelajaran dapat dilakuakn melaui 3 tahap, yaitu: (1) evaluasi tahap awal, (2) evaluasi harian, dan (3) evaluasi tahap akhir. Berikut hasil evaluasi penerapan metode iqra dalam peningkatan pembacaan Al-Qur'an bagi ibu-ibu Asyiyah ranting Ngadirejo.

a. Evaluasi tahap awal dimaksudkan untuk mengetahui kemampuan ibu-ibu dalam 
membaca Al-Qur'an berdasarkan kategori iqra/jilid.

b. Evaluasi harian dilakukan pada setiap akhir kegiatan yang dimaksudkan untuk mengetahui ketercapaian proses pembelajaran berjalan dan memotivasi ibuibu dalam peningkatan kemampuan membaca.

c. Evaluasi tahap akhir dilakukan untuk mengetahui peningkatan kemampuan ibuibu di akhir program.

Hasil analisis menunjukkan bahwa kelompok Al-Fadhilah Karang Tengah dan AlHidayah Klinggen berjalan lancar. Kehairan peserta $60 \%-90 \%$ setiap waktu belajar dan tutor tersedia cukup. Berdasarkan pengamatan dan dokumentasi administrasi, kemampuan semua peserta meningkat dengan bervariasi; iqra yang dipelajari meningkat jilidnya dan bacaan AlQur'an meningkat juz dan suratnya.

\section{Hasil Pengabdian Masyarakat}

Sesuai dengan tujuan pengabdian masyarakat ini, maka hasil penelitian ini meliputi: (a) peningkatan partsisipasi ibu-ibu anggota Aisyiyah dalam belajar memebaca AlQur'an dan (b) peningkatan kemampuan ibuibu dalam membaca Al-Qur'an.

\subsection{Peningkatan Partisispasi Peserta}

Partisipasi ibu-ibu anggota Aisyah dalam belajar membaca dapat diobservasi pada saat kegiatan sesuai jadwal. Kelompok Klinggen hanya masuk sekali dalam seminggu, yaitu setiap Sabtu pukul 15.30 - 17.00. Kelompok Al Fadhilah masuk tiga kali seminggu yaitu: Senin, Rabu, dan Kamis setiap pukul 15.30 - 17.00.

Pendampingan dilakukan sejak awal September 2020-April 2021. Kegiatan penyelenggaran kegiatan belajar Al-Qur'an selama pandemi menyesuaikan situasi pandemi. Oleh karena itu, kegiatannya tidak rutin. Hal ini dapat dilihat pada analisis data presensi pada Gambar 1.

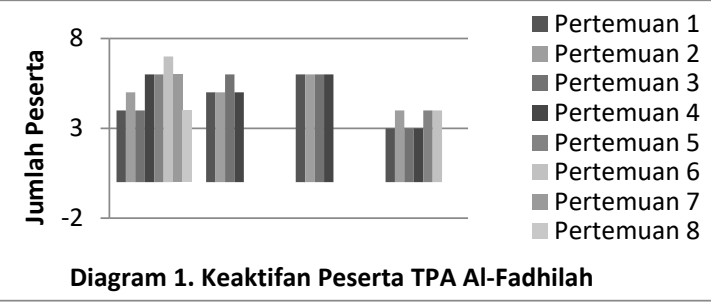

Gambar 1. Keaktifan peserta TPA Al-Fadhilah

Berdasarkan Gambar 1 di atas, memperlihatkan kegiatan TPA di Masjid Fadhillah dilaksanakan selama 4 bulan berturut-turut. Kegiatan TPA pada bulan September dilaksanakan penuh dengan 8 kali pertemuan dengan dihadiri paling banyak 7 orang pada pertemuan ke-6. Pada bulan
Oktober pelaksanaan kegiatan TPA hanya berlangsung pada pertemuan ke-4 karena libur Maulid Nabi. Hal yang sama juga terjadi pada bulan November yang dilaksanakan selama 4 kali pertemuan, karena sedang terjadi PPKM pada masa pandemi Covid-19. Kegiatan TPA pada bulan Desember dilaksanakan selama 6 kali pertemuan, karena pada akhir bulan terdapat libur natal dan tahun baru.

Kondisi yang hampir sama juga terjadi di kelompok Klinggen. Pelaksanaan pembelajaran sering terhenti karena PPKM di tempat tersebut. Data keaktifan peserta dari kelompok Klinggen tersaji pada Gambar 2.

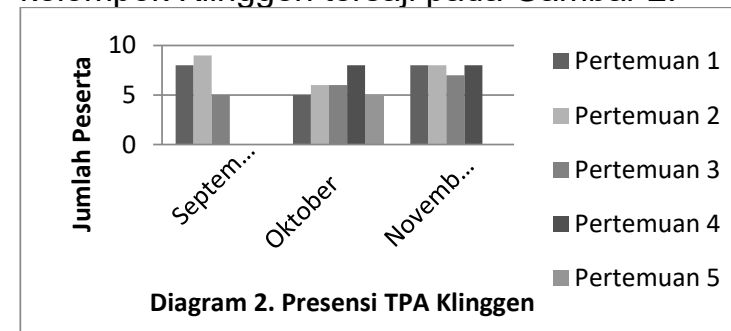

Gambar 2. Keaktifan peserta TPA Klinggen

Berdasarkan Gambar 1, dapat dinyatakan kegiatan TPA di Masjid Klinggen dilaksanakan selama 3 bulan. Kegiatan TPA pada bulan September dilaksanakan 3 kali pertemuan. Pada pertemuan kedua, peserta TPA hadir semua, yakni 9 orang. Bulan Oktober dilaksanakan setiap minggu dengan 5 kali pertemuan. Kegiatan TPA pada bulan November dilaksanakan selama 4 kali pertemuan. Kegiatan belajar Al-Qur'an di Masjid Klinggen tidak dilaksanakan sampai bulan Desember dikarenakan situasi pandemi Covid-19 yang menjadi pertimbangan.

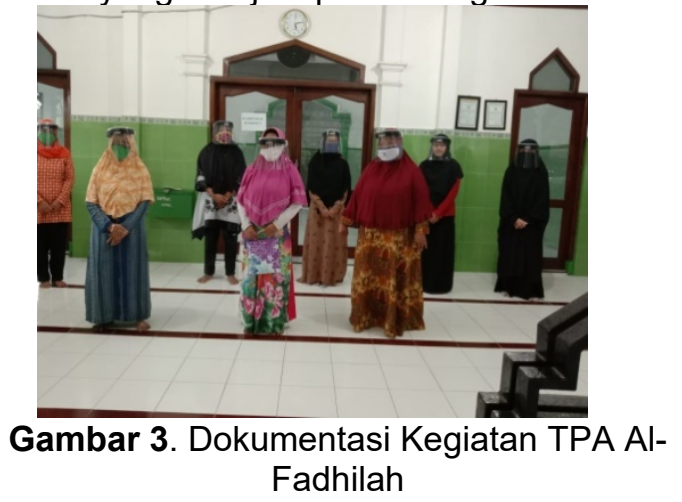

Penyelenggaraan kegiatan belajar AlQur'an selama pandemi dilaksanakan dengan protokol kesehatan yang ketat, yaitu memakai masker, mencuci tangan, memnggunakan handsanitizer, memakai face shield, dan menjaga jarak. Saat peserta dan tutor harus berhadap-hadapan secara individu, penggunaan masker dan face shield keduanya menjadi keharusan. Dalam pelaksanan 
protocol kesehatan ini, peserta sangat patuh, terbukti mereka memakai masker selama pembelajaran dan jaga jarak ketika duduk, maupun ketika sedang tutorial individual. Gambar 3 menunjukkan ibu-ibu sangat patuh kepada protokol kesehatan. Begitu pula, pada Gambar 4 terlihat antara tutor dan peserta patuh memakai masker dan menjaga jarak.

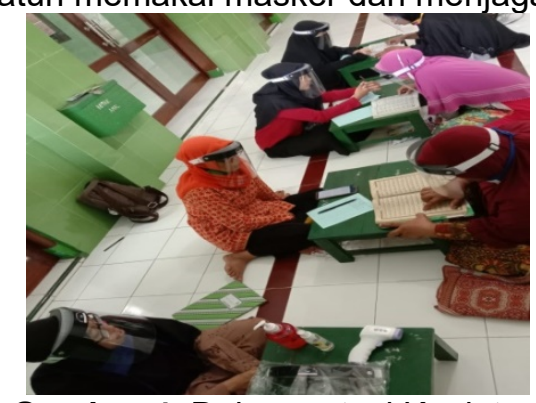

Gambar 4. Dokumentasi Kegiatan TPA AlHidayah

Kepatuhan terhadap protokol pada masa pandemi merupakan suatu usaha untuk memutus mata rantai penyebaran virus Covid19. Upaya yang dilakukan pemerintah dalam memutus virus ini meliputi (1) pembentukan satuan tugas Covid-19, (2) penerapan protokol kesehatan $5 \mathrm{M}$ yaitu mencuci tangan, memakai masker, menjaga jarak, mengurangi mobilitas dan menghindari kerumunan, (3) Pembatasan Pelaksanaan Kegiatan Masyarakt (PPKM), (4) Pembatasan Sosial Berskala Besar (PSSB), dan (5) penerapan new normal (Rachmadi, Wakhid Yuliyanto, Nurhayatun, \& Ari Waluyo, 2021). Selain itu, cara lain yang efektif dalam memutus rantai virus Covid-19 ialah dengan melakukan vaksinasi yang dapat dijadikan sebagai perlindungan diri terhadap penyebaran penyakit pada masa mendatang (Kartikawati \& Mayarni, 2021). Selalu menjaga lingkungan dan tidak membuang sampah sembarangan juga turut menjadi kebiasaan baru pada masa Covid19 (Wahid, Muslimah, Mahyona, \& Marlinae, 2021).

\subsection{Peningkatan Kemampuan Peserta}

Bacaan ibu-ibu anggota Aisyiyah peserta pendampingan ini terbagi menjadi tiga kelompok, yaitu kelompok iqra, kelompok Juz Amma, dan kelompok Al-Qur'an. Berdasarkan analisis terdapat kelompok iqra sejumlah 8 orang (40\%), kelompok Juz Amma sejumlah 3 orang (15\%), dan kelompok Al-Qur'an sejumlah 9 orang $(45 \%)$.

Dalam setiap pertemuan, bacaan ibu-ibu ini selalu meningkat, sesuai dengan tingkat bacaannya. Bagi kelompok iqra selalu dicatat jilid, halaman, dan lancar tidaknya membaca, bagi kelompok Juz Amma dicatat surat, ayat, dan lancar tidaknya membaca, serta bagi kelompok Al-Qur'an selalu dicatat surat, ayat, dan lancar tidaknya membaca. Pemantauan perkembangan bacaan peserta ini dicatat di dalam Kartu Prestasi.

Peningkatan kemampuan peserta sebagai berikut. Kelompok iqra beranggotakan ibu-ibu yang tingkat bacaannya bervariasi, ada jilid 2, 3, 4, dan 6 dengan halaman yang selalu meningkat dalam setiap pertemuannya. Kelompok Juz Amma juga memiliki tingkat bacaan surat yang bervariasi yaitu Al-Buruj, AlTakwir, An-Naziat, Al-Quraisy, Al-Bayyinah, AlAnbiya, dan An-Naba. Variasi tingkat bacaan pada kelompok Al-Qur'an terlihat dari tingkat ayat dan surat pada setiap juz, yakni Q.S. AlBaqarah ayat 24-Q.S. Al-Baqarah ayat 93, AnNisa ayat 19 - An-Nisa ayat 96 .

Dengan demikian, dapat disimpulkan bahwa berdasarkan pengamatan dan dokumentasi administrasi, kemampuan semua peserta meningkat dengan bervariasi: kelompok iqra meningkat jilidnya atau halamannya, kelompok Juz Amma bertambah surat dan ayat yang dibacanya, dan kelompok Al-Qur'an meningkat juz dan suratnya.

Pembelajaran Al-Qur'an dengan metode iqra terbukti meningkatkan kemampuan peserta TPA Al-Hidayah dan Al-Fadhilah yang merupakan ibu-ibu Aisyiyah. Dalam setiap pertemuan bacaan ibu-ibu selalu meningkat, baik tingkatan jilid iqra, surat pada Juz Amma, maupun ayat pada Al-Qur'an. Hasil penelitian (Subhan \& Ningsih, 2020) membuktikan bahwa metode iqra sangat efektif sebagai metode untuk mengajarkan Al-Qur'an dan meningkatkan kualitas bacaan Al-Qur'an peserta didik. Hal ini didukung dengan pengemasan metode iqra yang menarik dan mudah dipahami.

\section{SIMPULAN DAN SARAN}

Program penyelenggaraan belajar AlQur'an bagi ibu-ibu anggota Aisyiyah ini dapat disimpulkan berdasarkan keberhasilan program yang ditinjau dari kerjasama, proses penyelenggaraan kegiatan belajar Al-Qur'an, dan peningkatan kemampuan ibu-ibu dalam membaca Al-Qur'an.

Ditinjau dari terjadinya kerjasama, program ini dapat mempererat kerjasama antara Universitas Muhammadiyah Surakarta, PRA Ngadirejo, dan TPA Al-Hidayah. Tim pengadian UMS sebagai pencetus ide, pelaksana, dan pemantau kegiatan. PRA Ngadirejo sebagai lembaga yang memberi izin, memfasilitasi tempat, dan mendukung sosialisasi kegiatan. Adapun TPA Al-Hidayah menyediakan tutor/uztadz yang dibutuhkan. Ditinjau dari proses penyelenggaraan kegiatan belajar Al-Quran, program ini telah berhasil menyelenggarakan2 kelompok belajar 
membaca Al-Qur'an yang pesertanya ibu-ibu pada saat pandemi. Kelompok belajar ini adalah kelompok belajar di Masjid Al-Fadhilah Karang Tengah dan kelompok belajar di Masjid Al-Hidayah Klinggen. Metode yang diterapkan adalah metode iqra. Kelompok belajar ini tetap semangat belajar dengan menerapkan protokol kesehatan, walaupun kegiatan sering berhenti karena pandemi. Ditinjau dari peningkatan kemampuan peserta, program ini dapat meningkatkan kemamapuan peserta dalam membaca Al-Qur'an. Semua ibu-ibu yang aktif belajar mengalami peningkatan kemampuan, terbukti semua peserta mengalami penambahan tingkatan iqra dan halaman yang dibaca.

Pengabdian masyarakat ini merupakan lanjutan pada program sebelum pandemi. Hasil evaluasi dari program ini menunjukkan bahwa kegiatan selama pandemi kurang lancar karena adanya PPKM, sehingga kemampuan ibu-ibu juga belum tuntas. Oleh karena itu, kegiatan ini perlu ditindaklanjuti dengan kegiatan-kegiatan yang terprogram dan terus-menerus sehingga mampu mengurangi bahkan menghilangkan buta huruf Al-Qur'an.

\section{UCAPAN TERIMA KASIH}

Terima kasih kepada Lembaga Penelitian dan Pengabdian Masyarakat Universitas Muhammadiyah Surakarta yang telah membiayai kegiatan pengabdian ini.

\section{DAFTAR RUJUKAN}

Ahmad, B., Bonso, H., \& Samsiah. (2021). Pembinaan Metode Belajar dari Rumah bagi Wali Murid SD Yapis 2 Biah pada Masa Pandemik Covid-19. Selaparang: Jurnal Pengabdian Masyarakat Berkemajuan, 4(2), 374-380.

Fatimah, Nuraini dan Main Sufanti. (2013a). Pager bagi 'Aisyiyah Ranting Ngadirejo Kartasura tentang Pengarsipan dan Pemetaan Anggota sebagai Bentuk Penyelenggaraan Tertib Administrasi dan Pengelolaan organisasi yang Solid. Laporan Pengabdian kepada Masyarakat Universitas Muhammadiyah Surakarta.

Fatimah, Nuraini dan Main Sufanti. (2013b). Peningkatan Kemampuan membaca AlQuran Anggota Aisyiyah Ranting Ngadirejo Kartasura. Laporan Pengabdian Kepada Masyarakat. Surakarta: LPPM Universitas Muhammadiyah Surakarta.

Fikri, M., Ananda, M. Z., Faizah, N., Rahmani, R., Elian, S. A., \& Suryanda, A. (2021). Kendala Dalam Pembelajaran Jarak Jauh di Masa Pandemi Covid-19: Sebuah
Kajian Kritis. Jurnal Education and Development Institut Pendidikan Tapanuli Selatan, 9(1), 145-148. Retrieved from http://journal.ipts.ac.id/index.php/ED/articl e/view/2290

Jariah, A. (2019). Meningkatkan Kecerdasan Emosional Siswa Melalui Kebiasaan Membaca Al-Quran. Jurnal Studia Insania, $7(1)$, https://doi.org/10.18592/jsi.v7i1.2630

Kartikawati, E., \& Mayarni, M. (2021). Edukasi Vaksinasi Covid-19 Bagi Kelompok Aisyiah Ranting Kukusan Depok. Selaparang: Jurnal Pengabdian Masyarakat Berkemajuan, 4(3), 650-653. https://doi.org/10.31764/jpmb.v4i3.5182

Kelurahan Ngadirejo. (2017a). Profil Kelurahan Ngadirejo. $\quad$ http://kelurahanngadirejo.blogspot.co.id. Diunduh pada tanggal 10 Februari 2017.

Kelurahan Ngadirejo. (2017b). Monografi. http://kelurahan-ngadirejo.blogspot.co.id. Diunduh pada tanggal 10 Februari 2017

Nafiah, N., Ghufron, S., \& Hartatik, S. (2021). Pelatihan Dan Pendampingan Manajemen Pembelajaran Daring Ditengah Pandemi Covid 19 Bagi Guru Madrasah Ibtidaiyah. Selaparang: Jurnal Pengabdian Masyarakat Berkemajuan, 4(3), 540. https://doi.org/10.31764/jpmb.v4i3.4324

Permana, I., \& Rizqi, M. A. (2021). Peningkatan Kapasitas Pendamping dalam Deteksi Dini Masalah Kesehatan Mental Mahasoswa Unires UMY. Selaparang: Jurnal Pengabdian Masyarakat Berkemajuan Berkemajuan, 4(2), 52-55.

Pimpinan Pusat 'Aisyiyah. (2012). Anggaran Dasar dan Anggaran Rumah Tamah 'Aisyiyah. Yogyakarta.

Rachmadi, T. R., Wakhid Yuliyanto, Nurhayatun, \& Ari Waluyo. (2021). Pemberdayaan Masyarakat Dalam Pencegahan Penularan COVID-19 Melalui Sosialisasi Protokol Kesehatan di Pasar Rantewringin, Kecamatan Buluspesantren, Kabupaten Kebumen. JURPIKAT (Jurnal Pengabdian Kepada Masyarakat), 2(1), 126-136. https://doi.org/10.37339/jurpikat.v2i1.503

Sadiah, Maya, R., \& Wahidin, U. (2018). Implementasi Model Pembelajaran dalam Pemberantasan Buta Huruf Al-Quran di Majelis Taklim Nurul Hikmah Kampung Situ Uncal Desa Purwasari Kecamata Dramaga Kabupaten Bogor. ProsA PAI (Prosiding Al Hidayah: Pendidikan Agama Islam), 1, 1-18.

Sauri, S., Amri, N., Jumadi, A., Najwa, S., \& Hapsah, S. (2021). Implementasi Metode 
Iqra 'Dalam Pembelajaran Membaca Al Quran Di Tpq Dusun Lelonggek Desa Suntalangu. 1(1).

Subhan, \& Ningsih, F. (2020). Analisis Efektifitas Metode Iqro dalam Meningkatkan Kemampuan Membaca AlQur' an Siswa SD. Jurnal Pendidikan IPS, 10(2), 121-127.

Subir, M. S. (2019). Peran Guru dalam Meningkatkan Kemampuan Membaca AlQuran Siswa SMP Model Al-latiqomah. Transformasi: Jurnal Studi Agama Islam, 12(2), 104-120.

Sufanti, Main. (2013). Istiqomah: Modal pengelolaan TPA, dalam Majalah Bumayya, Edisi April 2013. Sukoharjo: Badan Koordinasi TPQ Kartasura.

Sufanti, Main, Ihsanudin, Muhammad dan Hidayah, Irfan. (2017). Rintisan Pemberantasan Buta Huruf Al-Quran bagi Kader 'Aisyiyah Ranting Ngadirejo, Kartasura. Laporan Pengabdian kepada Masyarakat Pengembangan Individual Dosen, Desember, 2017.

Suryanto, Joko. (2016). Strategi Dakwah Kultural Muhammadiyah dalam Mengimplementasikan Nilai-Nilai Pendidikan Islam di Masyarakat (Studi Empirik Pengurus Ranting Muhammadiyah Kelurahan Ngadirejo Kecamatan Kartasura Tahun 2016), Skripsi. Surakarta: Universitas Muhammadiyah Surakarta.

Wahid, A., Muslimah, S. R., Mahyona, V., \& Marlinae, L. (2021). Penyuluhan Kesehatan Masyarakat: Pengetahuan Mengenai BABS, Pengelolaan Sampah Rumah Tangga, dan Covid-19. Selaparang: Jurnal Pengabdian Masyarakat Berkemajuan Berkemajuan, 4(3), 717-722.

Yahya, K., D.A, L., Hapsari, N., S.N., A., Nuryasin, M., Bahirah, A., ... Deddt, M. (2019). Pemberantasan Buta Huruf Al-Qu ' ran Masyarakat Bangunrejo melalui Metode lqra. Prosiding Konferensi Pengabdian Masyarakat, 1, 17-19.

Zulfitria, \& Arif, Z. (2019). Penerapan Metode Iqro sebagai Kemampuan Dasar Membaca Al-Qur'an di TK Hiama Kids. PAUD Lectura: Jurnal Pendidikan Anak Usia Dini, 2(2), 57-66. 